\title{
技術報告
}

\section{複数種の半導体ガスセンサーを備えた混合ガス試料識別 装置の開発}

\author{
吉村忠与志 ${ }^{\circledR *}$, 斎藤 政晴 ${ }^{* *}$
}

(1990 年 7 月 27 日受理)

\begin{abstract}
化学物質のにおい識別を試みる目的でアンモニア, 硫黄化合物及びアルコールに選択的に応答を示す 10 種の半導体ガスセンサーを集合し，そのセンサ一応答データをパターン認識法を用いて解析し混合 ガス試料を識別するシステムを構筑した。パターン認識においてはポテンシャル関数法によるソフト ウェアを開発し，特徵変数の解析を行った．本システムをチオグリコール酸アンモニウムを主成分とす る市販の 5 種類のパーマ液に適用し，実用化の可能性を示すことができた。
\end{abstract}

\section{1 はじめに}

著者らは，パターン認識法を用いた複合ガスセンサー システムによる化学物質のにおいの自動認識に関する研 究を発表した ${ }^{122)}$.これらの報告では，試作したにおい センシングシステムの紹介, 化学物質のにおいの記述, センサーデー夕のパターン認識法を用いたデー夕解析, 及びサンプリング工程管理の立場から，七ンサ一応答に おける同時計測データの精度管理に重きを置いた。本報 告では，このシステムを“においセンシングシステム” とすることを目的に，システムの設計・開発を行い，そ の実用化にめどをつけることができ，更に，その念用と して混合系ガスサンプル（市販のパーマ液 1 剂）の識 別について，満足すべき成果が得られたので報告する.

$$
2 \text { 実験 }
$$

\section{$2 \cdot 1$ においセンシングシステム}

本システム (ハードウエア) は, 既報2)で報告したも のについて実用化を想定して改良を行い開発したもの で，テストボックスの断面図を Fig. 1 に示す. 本研究 で開発したテストボックスは特注品（ユニカス工業製） で，透明アクリル製二重槽（有効内容積 $4200 \mathrm{ml}$ ）の内 壁面に 10 個の半導体ガスセンサー(フィガロ技研製, Table 1 に示す) を取り付け，その前面にポリエチレン

* 福井 I.業高等専門学校丁.業化学科 : 916 福井県鯖江 书下司町

** [1華化学(株)研究開発本部：910 福井県福井市文京 4-23-1
製のエアノズルを放射線状にセットしたものである. 10 個の TGS センサーの選定は, 本研究の課題であるパー 又夜の組成に対して選択的に対応するものを基準に行っ た。特にアンモニアに選択性を示す TGS \# 824, 硫黄 化合物に選択性を示す TGS \# E71N 及びアルコールに 選択性を示す TGS \# 822 を用いた。空気は市販の圧縮 ボンベから電磁弁を通じて供給し，エアノズルによりセ

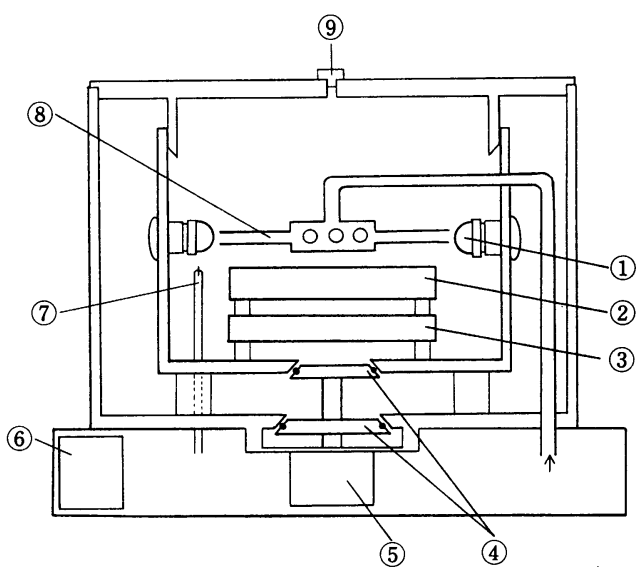

Fig. 1 Schematic sectional view of odor sensing system with plural semiconductor gas sensors

(1)TGS sensor; (2) circulating fan; (3)heater; (4) exhaust bulb; (5)air cylinder; (6)exhaust fan; (7) thermocouple detector; (8) air nozzle; (9) injection tube 
Table 1 Sensor elements and heater voltages

\begin{tabular}{cccl}
\hline $\begin{array}{c}\text { Sensor } \\
\text { number }\end{array}$ & Element & $\begin{array}{c}\text { Heater } \\
\text { voltage/V }\end{array}$ & \multicolumn{1}{c}{ Monitoring gas } \\
\hline 1 & TGS \#711 & 5 & carbon monoxide \\
2 & 825 & 5 & hydrogen sulfide \\
3 & 824 & 5 & ammonia \\
4 & E71N & 5 & sulfur \\
5 & 824 & 3.5 & ammonia \\
6 & 822 & 3.5 & alcohol \\
7 & E71N & 3.5 & sulfur \\
8 & 822 & 5 & alcohol \\
9 & 823 & 5 & general combustive gas \\
10 & $712 \mathrm{D}$ & 5 & carbon monoxide \\
\hline
\end{tabular}

ンサーに直接吹き付けられるようになっている。テスト ボックス内に温度調節器 REX-P9 (理化丁.業製) と ヒーター $40 \mathrm{~W}$, 熱電対の組み合わせで, $41 \pm 1{ }^{\circ} \mathrm{C}$ のボ ックス内温度制御を行った。システムの全体図を Fig. 2 の写真で示す.

エアブラシング法により，一咨空気環境の設定とガス センサーのエア洗浄を行った．各センサーに対する回路 電圧を $10.0 \mathrm{~V}$ に, ヒーター電圧を Table 1 のように一 定供給した。ガスセンサーの極性は直流使用で一方的に 使用し，極性を変えて用いることは行わなかった。かき 混ぜ用ファンは常時作動させ一定空気環境の設定を行っ た。かき混ぜは強制対流で，排気はエアシリンダーによ るダンパーの開閉とシロッコファンによる強制排気をシ ステム的に行った.

10 個のセンサー応答に対する同時計測は, パーソナ ルコンピューター NEG PG-9801RA に A/D コンバー ター \{コンテック製, AD 12-16S(98)H $\mathrm{H}$ を装備して, センサー抵抗の変化に対応する出力電圧をデータ計測の プログラムにより 0.2 秒間隔でデータ取り込みを行っ た. 各センサーの測定回路には負荷抵抗 $(4.7 \mathrm{k} \Omega$ ) が組 み込まれておりセンサーと負荷抵抗との閒の出力電圧

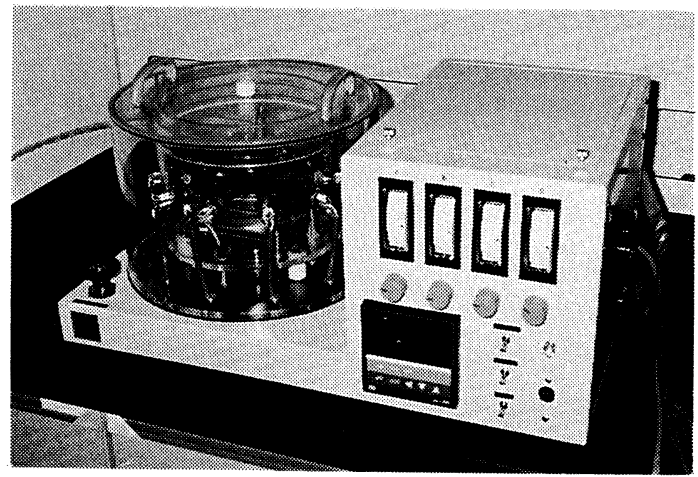

Fig. 2 External view of odor sensing system apparatus

（V）を計測した。計測したデー夕処理は既報 ${ }^{2)}$ と同じで ある．測定デー夕の標準偏差（SD）も出力電圧を基に 算出したので, 本報告では出力電圧 $(V)$ の值によって 考察を行う.

\section{$2 \cdot 2$ ガス試料の調製とサンプリング法}

使用した試薬は半井化学製一級品で室温時液体のもの をそのまま用いた．混合系ガス試料として市販のパーマ 液を 5 種類集めそのまま使用した。それらのパーマ液 の主な組成は Table 2 のようであり, その組成 (wt％) の残りはほとんど水であり，わずかに添加剤が 入っている. ガス試料の調製は，次のように行った。- ロフラスコ $(1000 \mathrm{ml})$ に試料を $20 \mathrm{ml}$ とり一方のロに ガスクロマトグラフの試料注人用シリコン栓を取り付 け，他方の口にエアバッファ (圧力補正) 用に注射器を 取り付けておく.そのフラスコを $30 \pm 0.5^{\circ} \mathrm{C}$ 温浴に入 れ恒温に保ち, 十分気液平衡に達したガス試料をその標 準試料とした.

サンプリング法は，圧力補償付きマイクロシリンジ

Table 2 Composition (wt \%) of five permanent wave solutions

\begin{tabular}{clllcccc}
\hline $\begin{array}{c}\text { Permanent wave } \\
\text { solutions }\end{array}$ & AT & MEAT & MEA & $\begin{array}{c}\text { Ammonia } \\
\text { aq. }\end{array}$ & 2-Propanol & $\begin{array}{c}\text { Ammonium } \\
\text { bicarbonate }\end{array}$ & Fragrance $^{\dagger}$ \\
\hline Sample 1 & 5 & 0 & 2 & 0.56 & 0 & 1.5 & 0.1 (type 1) \\
Sample 2 & 3 & 1.75 & 2 & 0 & 0 & 0.5 & $0.1($ type 1) \\
Sample 3 & 3 & 1.5 & 1.5 & 0 & 0 & 3 & 0.1 (type 1) \\
Sample 4 & 0.25 & 0 & 6 & 0 & 0 & 0 & $0.05($ type 2) \\
Sample 5 & 6.5 & 0 & 0 & 0 & 2 & 0 & $0.05($ type 3) \\
\hline
\end{tabular}

AT : ammonium thioglycolate; MEAT : monoethanol amine thioglycolate; MEA : monoethanol amine. $\dagger$ Type of fragrances 
( $5 \mathrm{ml}$, Precision Sampling Corp., Series D Gas) を用い て先のガス標準試料より適量を正確に採取し, 速やかに Fig. 1のガス注人口より注入した. ガス試料の注入量 は, $0.5 \mathrm{ml}$ から $5.0 \mathrm{ml}$ まで $0.5 \mathrm{ml}$ 刻みで, 10 点変化さ せて, センサーデータを計测した。

\section{$2 \cdot 3$ パターン認識法による特徴抽出と分類}

パ夕ーン認識法には, いろいろな方法があるが,ここ では教師付きパターン認識法の一つであるポテンシャル 関数法を用いる.この方法は, クラス確率分布の設定を 行うもので, 各特徴変数について訓練パターンをもとに それぞれのクラスに対する確率分布を求めるものであ $ろ^{3)}$.

\section{3 結果と考察}

\section{$3 \cdot 1$ 単一試料 (原液) の識別}

本システムの実用化 (混合系試料, パーマ液の識別) を想定して混合系試料（Table 2) のうち，それぞれの 単一試料について, チオグリコール酸, チオグリコール 酸アンモニウム, チオグリコール酸モノエタノールアミ ン, アンモニア水, 及びモノエ夕ノールアミンの原液か ら標準ガス試料を調製して, 各センサー応答のデータを 計測した. 上記の五つのガス種に対して特性值を求め た。ここで, 炭酸水素アンモニウム (10\% 濃度) につ いては，いずれのセンサーも応答信号を与えなかったの で, 特性值を求めなかった。 又, パーマ液に含まれてい る 3 種の香料についても濃度 $0.1 \mathrm{wt} \%$ の水溶液でセン サ一応答を調べたが，香料に関わる応答信号が得られな かったので, この場合も特性值を求めなかった．特性値 は，各原液のガス試料の注入量を変えて計測したデータ においてセンサー橎 10 值を基準 1 としたもので, ガ ス注入量の影響を除去し基準化したものである.

この特性值を用いて, 五つのガス種の識別をポテンシ ヤル関数法 ${ }^{3)}$ を用いてパターン認識を行った結果, 五つ のガス種のクラス識別では, それぞれの認識率はチオグ リコール酸, チオグリコール酸アンモニウム, チオグリ コール酸モノエタノールアミン, アンモニア水, 及びモ ノエタノールアミンの順で $36.5,64.0,62.2,74.3$, 及び $74.4 \%$ であった。 なかでも $36.5 \%$ と低い認識率を示し たチオグリコール酸はチオグリコール酸アンモニウムと チオグリコール酸モノエタノールアミンへの誤認識が目 立ち，五つのガス種においてはチオグリコール酸系化合 物の識別の難しさが分かった。次に，チオグリコール酸 系化合物 3 種についてのガス種の識別を, 同時にパ ターン認識を行った結果, 三つのガス種のクラス識別で
は，それぞれの認識率はチオグリコール酸，チオグリ コール酸アンモニウム, チオグリコール酸モノエタノ一 ルアミンの順で $78.9,70.7,82.9 \%$ となり, 誤認識はあ るものの五つのガス種のクラス識別時より認識率が高く なった. チオグリコール酸系化合物の識別ではこのよう にその系を絞り込んでいくパターン認識法が有効な方法 と思われる.

\section{$3 \cdot 2$ 単一試料（パーマ液相当の濃度）の識別}

パーマ液を想定して混合系試料（Table 2) のうち, それぞれの単一試料のパーマ液相当濃度 $5 \%$ のガス試 料（チオグリコール酸，アンモニア水，モノエタノール アミン及び 2-プロパノール) について, 各センサー応 答のデー夕を計測した。同様に特性値を求め, パターン 認識を行った結果，四つの化合物順でそれぞれの認識率 は 97.1，100，100 及び $89.6 \%$ という高い值を得ること ができ，4成分をほぼ完全に識別できた。

\section{$3 \cdot 3$ 市販パーマ液における識別}

Table 2 のような混合組成の市販パーマ液の 5 種のガ ス試料に対して各センサー応答のデータを計測した. 同 様に特性值を求め, パターン認識を行った結果を Table 3 に示す. Table 2 のパーマ液の順で, 80.7, 55.6, 47.7, 90.0 及び $93.3 \%$ という認識率を得た.サンプル 2 と 3 のパーマ液は, 表の值から分かるようにお互いの クラスへの誤認識があり, 認識率が低い。これは, チオ グリコール酸アンモニウムなどの含量がほぼ同じであ り, Table 2 で含量に差があるのがセンサ一応答を示さ なかった炭酸水素アンモニウムであることが原因で，こ れらのクラスへの誤認識率が大きく影響した值を示し た. 高い認識率を示したサンプル 1,4 及び 5 のパーマ 液は, アンモニア，モノエタノールアミン及び 2-プロ パノールが主体の混合組成のため先の二つのパーマ液と は，ほぼ満足な識別をすることができた．次に，90\% 以上識別できた後者二つのパーマ液を除いて, 前者三つ （サンプル 1, 2 及び 3) のパーマ液だけでパターン認識 を行った結果を Table 4 に示す。それぞれの認識は 90.0，89.0 及び $71.8 \%$ となり，ほぼ実用的な識別の可 能性を示した。これらの三つのパーマ液に対する結果の うち，ポテンシャル関数法による確率分布值をヒストグ ラム化したのがFig. 3 である.このように，三つのク ラスにおける各 TGS センサーの応答が異なる確率分布 值を示していることが分かった。これより，市販パーマ 液 1 剤の 5 種類のサンプルについてほぼ実用的な識別 をすることができたと考えられる. 
Table 3 Recognition rate of the permanent wave solutions

\begin{tabular}{|c|c|c|c|c|c|c|}
\hline \multirow{2}{*}{$\begin{array}{l}\text { Permanent wave } \\
\text { solutions }\end{array}$} & \multirow{2}{*}{$\begin{array}{l}\text { True } \\
\text { class }\end{array}$} & \multicolumn{5}{|c|}{ Calculated class, $\%$} \\
\hline & & 1 & 2 & 3 & 4 & 5 \\
\hline Sample 1 & 1 & 80.7 & 10.2 & 9.1 & 0 & 0 \\
\hline Sample 2 & 2 & 3.8 & 55.6 & 24.6 & 0 & 16.0 \\
\hline Sample 3 & 3 & 20.3 & 27.3 & 47.7 & 0 & 4.7 \\
\hline Sample 4 & 4 & 0.8 & 0 & 9.2 & 90.0 & 0 \\
\hline Sample 5 & 5 & 3.4 & 0 & 3.4 & 0 & 93.3 \\
\hline
\end{tabular}

Table 4 Recognition rate of the permanent wave solutions

\begin{tabular}{ccccc}
\hline $\begin{array}{c}\text { Permanent } \\
\text { wave } \\
\text { solutions }\end{array}$ & $\begin{array}{c}\text { True } \\
\text { class }\end{array}$ & \multicolumn{3}{c}{ Calculated class, \% } \\
\hline Sample 1 & 1 & 90.0 & 0 & 2 \\
Sample 2 & 2 & 0 & 89.0 & 10.0 \\
Sample 3 & 3 & 16.5 & 11.7 & 71.0 \\
\hline
\end{tabular}

新たに開発したにおいセンシングシステムは, 本研究 においてパーマ液のような複雑な混合系試料の識別にほ ぼ実用化のめどを与えたと思われる。そこで，従来の測 定法であるガスクロマトグラフィーによる追試実験を行 った．上に記述した実験はほとんど追試した．5\%濃度 の単一試料におけるガスクロマトグラムは, アンモニア 分析用カラム (Chromosorb 103 60/80) で, モノエ夕 ノールアミンが保持時間 $8.37 \mathrm{~min}$ で, 2-プロパノール

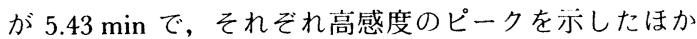
は, チオグリコール酸モノエタノールアミンが保持時間 8〜10 min の幅広いピークを示しただけで，チオグリ コール酸やアンモニアは高感度なピークは示さなかっ た.

Table 2 の組成の 5 種類の市販パーマ液については, 混合試料でもあり，これらのクロマトグラムのクロマト パック出力のままでは微小なピークは縦軸のスケールを 上げれば多少の情報量が多くなると思われるが, 全体で のクロマトグラムを比較するために縦軸のスケールは一 定で検討した。これらの五つのクロマトグラムを見比べ ると，サンプル 5 だけは別ものと識別できるが，それ 以外のサンプル 1 からサンプル 4 の四つのパーマ液は クロマトグラムのパターンとしてほとんど区別は困難で あった。

以上まとめると，においを発する混合系サンプル（市 販パーマ液) を識別できるシステムを開発して，ほぼ実
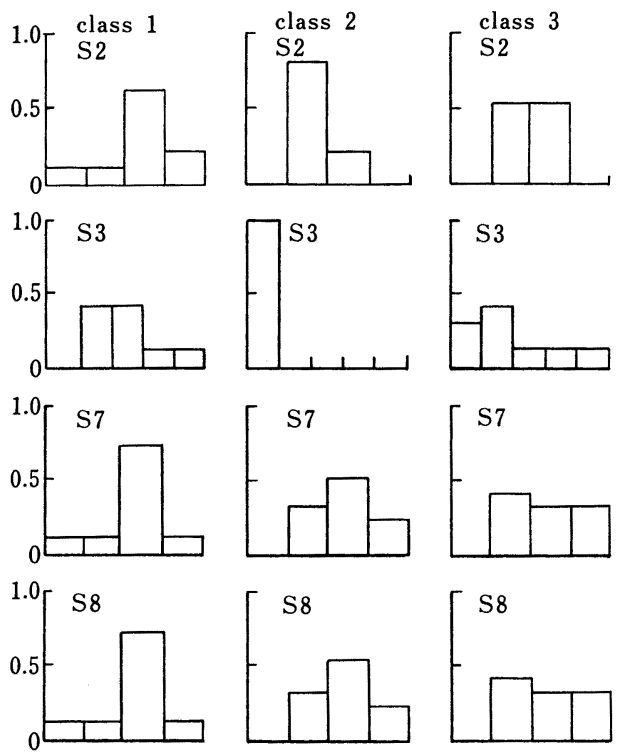

Decision number

Fig. 3 Histograms of the probable distribution values of permanent wave solutions (samples 1, 2 and 3) by a potential function method

Class numbers correspond to sample numbers respectively.

用化のめどをつけることができた. 本研究で, 従来の分 析方法とは異なるシステムを開発し混合系試料の識別を 可能にしたことは意義深いものと思われる. 今後は, 企 業生産におけるパーマ液（原料及び製品）の質と量の管 理への適用を検討し, 更に, 新規のガス選択性センサー を組み込むことにより，他の混合系ガス試料についても その適用範囲を広げたいと思っている.

最後に, 本研究は平成元年度福井県産業振興財団研究助 成費によって行われたことを記し, 謝意を表すと共に, 研 究を推進及び補助してくれた日華化学(株)の中谷公重嬢 と, 福井下.業高専の酒野吉央君に心から感謝申し上げる. 


\section{文献}

1) H. Abe, T. Yoshimura, S. Kanaya, Y. Takahashi, Y. Miyashita, S. Sasaki : Anal. Chim. Acta, 194, 1 (1987).

2) 吉村忠与志: 分析化学, 3,612 (1988).

3) D. Coomans, I. Broeckaert: "Potential Pattern Recognition in Chemical and Medical Decision Making", p. 59 (1986), (Research Studies Press, England).

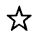

Development of recognition apparatus of mixed gas samples using plural semiconductor gas sensors. Tadayosi Yoshimura ${ }^{*}$ and Masaharu Saitou ${ }^{* *}\left({ }^{*}\right.$ Fukui National College of Technology, Geshi-cho, Sabae-shi, Fukui 916; ${ }^{* *}$ Nicca Chemical Co., Ltd., 4-23-1, Bun- kyo, Fukui-shi, Fukui 910)

An automated odor-sensing system using several semiconductor gas sensors has been developed. This system was applied to the recognition of mixed gas samples, such as commercially available permanent wave solutions. The recognition of the mixed gas samples showed a good agreement with that by GC. This automated odor-sensing system will be of practical use as a recognition method of mixed gas samples.

(Received July 27, 1990)

\section{Keyword phrases}

odor-sensing system; pattern recognition techniques; semiconductor gas sensor; recognition of mixed gas samples. 